\title{
Anúncio publicitário e provérbio: os gêneros discursivos pela nova retórica
}

\author{
Crisvânia Santos \\ PUC - Rio
}

\begin{abstract}
Os historiadores e arqueólogos descobrirão um dia que os anúncios de nossa época constituem o mais rico e mais fiel reflexo cotidiano que uma sociedade jamais forneceu de toda uma gama de atividades. Marshall Mc Luhan
\end{abstract}

\begin{abstract}
Resumo
Há um consenso de que os provérbios sintetizam uma regra social ou moral transmitidas de geração em geração. O provérbio é compacto e fácil de ser memorizado. Considerando o seu funcionamento discursivo, este artigo objetiva analisar os efeitos de sentido causados pela sua reconstrução no gênero anúncio publicitário. Assim, foram selecionados três anúncios (um de cerveja, um de carro e outro de pneu) veiculados na Revista Veja, anunciados no período de 2002 a 2012. Os pressupostos teóricos são os de Miller (1994) e Bazerman (2005), representantes da Nova Retórica, que considera os gêneros como formas de ações sociais. Os resultados demonstram que a publicidade transgride os provérbios para comunicar novas mensagens a partir de enunciados convencionalmente aceitos pela população. Deste modo, seu discurso torna-se ainda mais persuasivo.
\end{abstract}

Palavras-chave: Gêneros discursivos, provérbios, anúncio publicitário.

\begin{abstract}
There is a consensus that proverbs, in general, summarize social or moral rules passed on through time among generations. A proverb is usually short and easy to be kept in mind. Considering the discursive function, this article is concerned with the analysis of the reconstruction of proverbs in advertising campaigns as a genre. Three ads were selected (beer, car and tire ads) from Veja magazine (a prestigious Brazilian magazine) in the decade of 2002-2012. Our theoretical background is based upon Miller (1994) and Bazerman (2005), New Rhetoric scholars whose works consider genres as types of social action. The results show that advertising twists the proverbs to express new messages that originate in sayings commonly accepted by language users, which makes its discourse even more persuasive.
\end{abstract}

Keywords: Discourse, proverbs, advertising campaigns.

\section{CONSIDERAÇÕES INICIAIS}

Desde muito cedo, convivemos com o gênero anúncio publicitário impresso, que está por toda a parte (revistas, jornais, embalagens, etc.). Cada vez mais as empresas o usam para divulgar seus produtos e manterem-se em um mercado extremamente competitivo. Nesse contexto, a fim de produzir uma comunicação adequada para públicos variados, e cumprir sua função social, os anúncios se utilizam de várias 
estratégias linguísticas para a construção de um enunciado criativo e persuasivo, incorporando, inclusive outros gêneros, como os provérbios, por exemplo, que são suscetíveis de deslocarem seus sentidos cristalizados para novos sentidos.

Com esse pano de fundo, este artigo tem por objetivo analisar os efeitos de sentido veiculados pela utilização de provérbios re-construídos nos anúncios publicitários. A fim de abordar essa questão e outros aspectos relevantes acerca dos gêneros, adoto como fundamentação teórica a proposta da Nova Retórica para a análise dos gêneros discursivos. Nesse percurso, conto com o apoio teórico dos seguintes autores: Bakhtin (1994), Miller (1994) e Bazerman (In Dionisio \& Hoffnagel, 2005).

Compreender as ações que os gêneros realizam, sobretudo as dos anúncios publicitários, é uma forma de atuar na sociedade criticamente. Daí a justificativa do trabalho.

\section{O QUE SE ENTENDE POR GÊNEROS DISCURSIVOS ${ }^{1}$}

$\mathrm{O}$ estudo dos gêneros passou por transformações ao longo dos tempos. $\mathrm{Na}$ Grécia Antiga, quando se falava em gêneros era em referência aos gêneros clássicos, que eram definidos por suas formas poéticas: lírico, épico e dramático. Essa tríade clássica foi a base dos estudos desenvolvidos pelas teorias literárias para a identificação e classificação de outros gêneros: o romance, a novela, o conto, etc. Observamos, assim, que o estudo dos gêneros esteve ligado, especificamente, ao campo literário. Mas, a partir dos estudos de Bakhtin sobre a linguagem e a literatura, no início do séc. XX, houve uma reavaliação no conceito de gêneros, que ele chamou de gêneros do discurso.

O pensador russo foi o primeiro a considerá-los não somente pelas características artístico-literárias, mas pelo viés dialógico do processo comunicativo. Assim, a noção de gêneros foi ampliada, abarcando todos os usos da linguagem, e o enunciado foi eleito como a unidade da comunicação verbal, uma vez que pressupõe a presença de sujeitos que interagem num determinado contexto social e que partilham de uma mesma cultura, ou seja, está em contato imediato com a realidade. Bakhtin (1992, p. 280) esclarece que:

Todas as esferas da atividade humana, por mais variadas que sejam, estão relacionadas com a utilização da língua (...). O enunciado reflete as condições específicas e as finalidades de cada uma dessas esferas, não só por seu conteúdo

\footnotetext{
${ }^{1}$ Há uma boa discussão sobre a questão "gêneros discursivos" e "gêneros textuais" em Rojo (in: Meurer; Bonini; Motta-Roth, 2005, p. 184-207), mas aqui não vamos entrar nesse mérito. Utilizaremos sempre "gêneros discursivos".
} 
temático e por seu estilo verbal, ou seja, pela seleção operada nos recursos da língua - recursos lexicais, fraseológicos e gramaticais - mas também, e, sobretudo, por sua construção composicional.

Segundo o autor (Idem, p. 302), aprendemos a falar construindo enunciados e não orações isoladas, que não passam de construções teóricas puramente gramaticais. Os gêneros do discurso organizam a nossa fala da mesma maneira que a organiza a sintaxe. Bakhtin define os gêneros discursivos como tipos de enunciados relativamente estáveis que têm um conteúdo temático, um estilo próprio e uma composição ${ }^{2}$, e que estão vinculados a situações típicas de comunicação social.

O conteúdo temático, o estilo e a composição estão ligados no todo do enunciado (gênero) e são igualmente determinados pela especificidade de um determinado campo da comunicação. Por exemplo, reconhecemos um artigo de opinião porque do ponto de vista da composição, levamos em conta a forma de organização e a distribuição das informações; do ponto de vista do conteúdo temático, geralmente, consta de acontecimentos de ordem política, econômica, social, histórica ou cultural; em se tratando de estilo, normalmente, apresenta um grau formal de comunicação. Ou seja, as escolhas que fazemos ao produzirmos um discurso não são aleatórias nem completamente espontâneas, mas decorrentes de algumas condições específicas em que é realizado; a partir das finalidades e intenções é que o discurso se organiza. Como as esferas de utilização da língua são extremamente heterogêneas, também os gêneros apresentam grande heterogeneidade.

O filósofo acrescenta que as mudanças históricas por quais passa a humanidade estão ligadas às mudanças dos gêneros (Ibidem, p. 280). Como exemplo, cito o e-mail (que é, ao mesmo tempo, suporte) como gênero da cultura eletrônica, advindo das exigências de um mundo globalizado e informatizado (Paiva in Marcuschi \& Xavier, 2004). Como afirma Bakhtin, os gêneros são correias de transmissão entre a história da sociedade e a história da linguagem.

Nessa diversidade dos gêneros, ele trata de distinguir os que seriam primários (simples) dos secundários (complexos). Os primeiros referem-se aos gêneros usados no cotidiano das relações sociais (diálogo, saudações, ordens, carta, etc.), já os segundos

\footnotetext{
${ }^{2}$ Fazendo um aparte, Rojo (2005, p. 195-196) propõe uma terminologia diferente para a definição de gênero proposta por Bakhtin. Para a autora, gênero é forma (de discurso, de enunciação). O corolário desses termos é tema ou a significação acrescida da ideologia e da valoração, único fim de um enunciado vivo. Por isso, forma de discurso, de enunciação e não forma de enunciado. Ela afirma que a definição bakhtiniana de gênero (tipo de enunciado relativamente estável que tem composição, um tema e um estilo próprios) estaria muito próxima de uma linguística do texto.
} 
abrangem as práticas sócio-ideológicas mais elaboradas culturalmente (romances, dramas, pesquisas científicas, publicidades, etc.). Os secundários se formam a partir dos primários, absorvendo-os e transformando-os. Nesse processo de transformação, o secundário traz as características do primário, acrescenta novas características da esfera discursiva em que circula e se realiza como um novo gênero (Ibidem, p. 282).

O autor adverte que se não existissem os gêneros do discurso e se não os dominássemos, se tivéssemos de criá-los pela primeira vez no processo da fala, a comunicação verbal seria quase impossível (Ibidem, p. 302). Logo, comunicamo-nos através dos gêneros e quanto mais os dominamos, melhor os empregamos e maior é a nossa inserção em diversas circunstâncias e atividades sociais.

Os estudos de Bakhtin abriram caminhos para três tradicionais correntes de estudos do gênero que se desenvolveram aproximadamente no mesmo período, entre as décadas de 80 e 90 (Hyon, 1996, p. 696). Cito-as aqui, em linhas bem gerais, para contextualizar a teoria de gênero adotada neste artigo: (i) a teoria australiana (centrada na linguística sistêmico-funcional desenvolvida por Halliday) estuda o gênero como uma atividade social desenvolvida em um contexto. Nessa teoria, com enfoque mais pedagógico para o ensino da língua em sala de aula, a descrição do gênero se dá pela observação dos elementos obrigatórios e opcionais. Seus representantes são Martin e Hasan; (ii) a abordagem instrumental, ou inglês para fins específicos (ESP), originada nos Estados Unidos, vê os gêneros como tipos de textos orais e escritos definidos por suas propriedades formais, bem como por seus propósitos comunicativos dentro dos contextos sociais. Aqui, o gênero é analisado pelos seus movimentos e etapas para descrição de seu padrão de organização. A proposta dessa linha é ajudar os falantes não nativos de inglês a dominarem as funções e convenções linguísticas de gêneros que eles precisam ler e escrever em contextos acadêmicos ou profissionais. Seus representantes são Swales e Bhatia; (iii) e os estudos da Nova Retórica, também norte-americana, cuja ênfase está nos fins sociais que os gêneros cumprem. Para tanto, investiga as práticas sociais e discursivas em diferentes contextos educacionais ou profissionais. Assim, analisa as regularidades nos tipos de discurso em conexão com as regularidades das atividades desempenhadas pelas pessoas. Os representantes teóricos dessa linha são Miller e Bazerman. A Nova Retórica é a que está mais intimamente ligada à Bakhtin.

Miller (1994, p. 24, 38) diz que a definição de gênero não deve ser centrada na substância ou na forma do discurso, mas na ação que ele realiza. Dessa forma, a análise do gênero deve ser feita a partir do processo e não do produto, a fim de que seja 
entendida a ação retórica, ou seja, o propósito. Por isso, os pesquisadores da Nova Retórica não privilegiam o ensino da estrutura do gênero, mas sim a sua função social e seu contexto de uso. A autora afirma que o que aprendemos quando dominamos um gênero não é apenas um padrão de formas linguísticas, mas sim uma forma de realizar linguisticamente objetivos específicos em situações sociais particulares. Miller (1984 apud Motta-Roth, p. 184) entende os gêneros como artefatos culturais, formas recorrentes e significativas de agir em conjunto, que põem alguma ordem no contexto da vida em coletividade.

Em uníssono com Miller, embora empregando terminologia diferente, Bazerman entende os gêneros como fatos sociais sobre os tipos de atos de fala que as pessoas podem realizar e sobre os modos como elas os realizam. Os fatos sociais consistem em ações sociais significativas realizadas pela linguagem ou atos de fala. Esses atos são realizados através dos gêneros. Dessa forma, gêneros emergem nos processos sociais em que pessoas tentam compreender umas às outras suficientemente bem para coordenar atividades e compartilhar significados com vistas a seus propósitos práticos (Bazerman in Dionisio \& Hoffnagel, 2005, p. 31). Em outras palavras, os gêneros moldam as intenções dos falantes, permitindo um quadro interpretativo da situação comunicativa.

Segundo o autor (In Paré \& Smart, 1994, p. 146), a maioria dos gêneros tem características de fácil reconhecimento que sinalizam a espécie de texto que são. Geralmente, essas características estão relacionadas com as funções principais ou atividades realizadas pelo gênero. Assim, reconhecemos quando se trata de um manual de instruções, da capa de um jornal ou de uma publicidade, por exemplo. Além das características próprias, o gênero também está associado a um padrão de regularidade na produção e na interpretação desses textos nas relações sociais entre escritores e leitores.

Paré e Smart, baseados em Bazerman, listam uma série de atividades que podem ser investigadas no processo de composição do gênero, a saber: o evento inicial da produção do texto; as fases da coleta e análise de informações para compô-lo; a escrita e reescrita individual; as atividades colaborativas (revisão de diversas versões feitas por outros); e a tecnologia usada na produção. Ao se referirem às regularidades na prática de leitura, os autores propõem que sejam pesquisadas as seguintes atividades: a maneira como um leitor se aproxima do texto; como o leitor negocia com o texto, interagindo, escolhendo o que lê e o que pula; como o leitor constrói o conhecimento através do 
texto; e como os leitores usam o resultado do conhecimento para tomar decisões (Idem, p. 150-152).

Marcuschi (2002, p. 19) também trabalha na mesma perspectiva de Miller e Bazerman ao definir gêneros como entidades sócio-discursivas e formas de ação social em qualquer situação comunicativa. $O$ autor afirma que as distinções entre um gênero e outro não são predominantemente linguísticas e sim funcionais. Ou seja, os gêneros não se definem por sua forma, mas por sua função. Logo, um poema pode assumir a forma de uma receita culinária e, ainda assim, continuar sendo poema por conta de seu propósito comunicativo.

Esse fenômeno, alusivo à hibridização ou mescla de gêneros é denominado de intertextualidade intergêneros (Idem, p. 31) - um gênero com a função de outro. Esta maleabilidade ou ausência de rigidez e capacidade de adaptação está perfeitamente de acordo com Miller (a análise do gênero deve partir da ação que ele realiza e não de sua forma) e Bakhtin (relativa estabilidade dos gêneros). Como pontua Marcuschi, este aspecto é central na designação de muitos gêneros que são definidos basicamente por seus propósitos (funções, intenções, interesses) e não por suas formas.

Em relação à hibridização dos gêneros, a publicidade opera de maneira produtiva como uma forma de chamar a atenção do público para o produto ou serviço que está sendo oferecido. A meu ver, é um convite para que as pessoas interpretem com maior afinco o enunciado e assim sejam influenciadas para o consumo.

Assim, a teoria de gênero como ação social o reconhece como organizador e estruturador das ações e interações sociais, cuja análise privilegia a situação enunciativa e a finalidade do gênero. A partir dessa análise são observadas as características linguísticas que refletem no gênero os aspectos da situação comunicativa. Portanto, o objetivo não é a descrição das propriedades e das formas de composição do gênero, mas a configuração de significado ao serem relacionados o objetivo de seu uso e seu contexto.

Para a Nova Retórica, as regularidades do gênero são devidas não às formas fixas da língua, mas às regularidades e similaridades das relações sociais numa determinada esfera de comunicação (Miller, 1994, p. 29. Bazerman apud Carvalho, 2005, p.135). Esta concepção concorda com a teoria bakhtiniana, que prevê um conjunto de regularidades (conteúdo temático, estilo e construção composicional) determinadas pelas condições em que um enunciado (o gênero) é produzido em circunstâncias específicas de práticas da linguagem. 


\section{O GÊNERO ANÚNCIO PUBLICITÁRIO}

Construído de forma a impor, nas linhas e entrelinhas, valores, mitos e outras elaborações simbólicas, o anúncio publicitário (aqui vamos abstrair a parte imagética que geralmente acompanha a textual) tem a finalidade de exercer ação psicológica sobre os receptores para conseguir deles uma mudança comportamental (adesão ou compra) em relação ao objeto oferecido, que pode ser: a promoção de uma ideia, de um serviço, da marca de um produto ou do nome de uma empresa.

Monnerat (2003, p. 15) resume a proposta da publicidade nas seguintes palavras: a publicidade é uma das várias forças de comunicação que deve levar o consumidor através de vários níveis (desconhecimento $\rightarrow$ conhecimento $\rightarrow$ compreensão $\rightarrow$ convicção $\rightarrow$ ação) ao objetivo visado, a compra do produto (ação).

Conforme o esquema da autora, a publicidade cria uma necessidade no consumidor para a qual, até então, ele não havia atentado. O interesse pelo produto oferecido não se dá apenas pela sua funcionalidade, mas também pelo prestígio que proporciona. A publicidade associa relações subjetivas como satisfação da autoestima e status, por exemplo, à utilidade do produto. Desse modo, o consumidor convencido de que determinado produto é indispensável para o seu bem-estar, decide-se pela compra.

Como pontua Sandmann (2005, p. 34), sendo a linguagem publicitária, até certo ponto, reflexo e expressão da ideologia dominante, dos valores em que se acredita, ela manifesta a maneira de ver o mundo de uma sociedade em certo espaço da história. Nos termos de Bakhtin (1979, p. 31), onde há signo, há ideologia, pois "todo signo é ideológico; a ideologia é um reflexo das estruturas sociais". Daí a importância de se ler um texto de forma crítica, consciente de que as ideologias nas quais um texto é baseado podem vir a moldar o comportamento das pessoas (Sabrina \& Heberle, 2002, p.178).

Ideologicamente, o discurso publicitário funciona em três dimensões: a) na construção das relações entre o anunciante e o público; b) na construção da imagem do produto; e c) na construção do consumidor como membro de uma comunidade (Monnerat, 2003, p. 46). Esta última é a maior tarefa da publicidade. O receptor ideal pertence a uma comunidade cujos valores, necessidades e gostos representa. Desse modo, temos uma "comunidade de consumidores".

Para Carvalho (2003, p. 15), o anúncio publicitário constitui o canal de publicidade por excelência, estabelecendo uma ligação direta entre a oferta e a procura. 
De acordo com o veículo (revista ou jornal), a técnica de construção será diferente. A revista, diferentemente do jornal, favorece procedimentos gráficos mais sutis e eficazes (nuances de cor, tipos de letras, detalhes da imagem). Além disso, há uma diferença substancial entre o público de cada veículo: o público do jornal é mais generalizado, incluindo diversas faixas etárias, sociais e econômicas, enquanto a revista tem um público-alvo diferenciado e específico.

A autora (Idem, p. 13) acrescenta que o anúncio publicitário tem a forma de diálogo (dá a ilusão de que se dirige a alguém individualmente), mas produz uma relação assimétrica, só a voz do emissor prevalece no circuito da fala; o receptor, contudo, é atingido pela atenção desse emissor em relação ao objeto. Como a relação estabelecida entre anunciante e possível cliente se dá como um diálogo, os verbos, geralmente, estão em terceira pessoa nos anúncios. É constante o uso do pronome pessoal "você" e dos possessivos "seu", "sua”, assim como o uso do "a gente". Esses elementos da língua individualizam o destinatário, tornando-o íntimo, alguém muito especial e não mais um entre a massa.

Segundo Sandmann (2005, p. 12), o grande desafio da publicidade é fazer com que o público preste atenção ao seu texto. Para tanto, explora, estrategicamente, os recursos da língua para a construção do anúncio, tais como: os fonéticos - rimas, ritmos, evocação de ruídos (onomatopéias) e motivação sonora (aliteração, assonância); os léxico-semânticos - criação de novos termos, mudanças de significado, construção ou desconstrução de palavras, clichês, frases feitas, provérbios, termos emprestados e usos conotativos e denotativos; e os morfossintáticos - flexões diferentes e grafias inusitadas, relações novas entre elementos e sintaxe não-linear. Tais recursos, ao serem usados, passam a exercer as funções de persuasão, representação da realidade e sedução dos interlocutores.

Aplicando o que diz a Nova Retórica (são as regularidades das relações sociais que determinam as regularidades linguísticas dos variados tipos de discurso), o anúncio publicitário simula (uma vez que só a voz do anunciante está presente) um diálogo com o consumidor, cujo objetivo é persuadi-lo à compra. Logo, a intenção do convencimento por parte do anunciante exige que ele elabore seu texto estrategicamente com os recursos linguísticos mais adequados para esta função (verbos no imperativo, pronomes pessoais, etc.). 


\section{O GÊNERO PROVÉRBIO}

Paremiologia é o estudo científico sobre os provérbios. Há várias associações internacionais de paremiologistas que realizam conferências e publicações periodicamente $^{3}$. No Brasil, porém, esse é um campo ${ }^{4}$ ainda pouco explorado, principalmente no que diz respeito ao ensino de língua portuguesa. São poucos os livros didáticos de português que mencionam ${ }^{5}$ provérbios. Também no meio acadêmico, na maioria dos artigos e dissertações que encontrei, geralmente, os provérbios estão associados ao ensino de língua estrangeira.

O provérbio nasceu muito antes da história escrita. Ao longo dos séculos, esse importante gênero foi transmitido através das tradições orais. Os exemplos mais antigos datam de 2600-2550 a. C. Os provérbios sumérios inscritos nas tabuinhas de argila foram descobertos em 1963, a 150 quilômetros a sudeste de Bagdá, no entanto, as tradições orais são muito mais antigas (Schipper, 2012, p. 26).

Em seu dicionário de gêneros textuais, Costa (2009) define provérbio como "frase curta, geralmente de origem popular, com rima e ritmo, rica em imagens, que sintetiza um conceito a respeito da realidade ou uma regra social ou moral". Esta é uma definição centrada mais na forma, já a definição de Obelkevich (1997, p.45) está mais de acordo com a teoria de gêneros da Nova Retórica:

O que define o provérbio não é sua forma interna, mas sua função externa, e esta, comumente, é moral e didática: as pessoas usam os provérbios para dizer a outras o que fazer ou que atitude tomar em relação a uma determinada situação. Assim, os provérbios são "estratégias para situações", mas estratégias com autoridade, que

\footnotetext{
${ }^{3}$ O paremiologista americano Archer Taylor é considerado pelos estudiosos como o marco de surgimento da paremiologia moderna. A Universidade de Vermont (EUA) mantém uma publicação regular, herdeira de outra que começou na Universidade de Helsinki. A Universidade da Tasmânia (Austrália) publica um jornal eletrônico para o estudo dos provérbios (http://www.deproverbio.com/index.php). Africanos têm a sua home page para curiosíssimos provérbios do continente (www.afriprov.org). Por exemplo, de Uganda: "Quando dois elefantes brigam, é o capim que sofre." Ou da Nigéria: "A mulher cujo fillho foi comido por uma feiticeira, é quem melhor conhece os males da feitiçaria". Existe uma editora que se dedicou a descobrir provérbios na obra de Winston Churchill (Grenwood Publishing Group). A Penfield Press tem uma coleção de livros de provérbios de diferentes países (Iowa City). A Universidade de Harvard oferece excelentes ensaios sobre o assunto, que começaram a ser publicados em 1931. Enfim, há várias publicações pelo mundo e muito pouco no Brasil.

${ }^{4}$ Existe a Associação Brasileira de Fraseologia, cuja presidente, eleita em 2011, é Maria Luisa Ortíz Alvarez, atuante na Universidade de Brasília. No entanto, eles se dedicam a todos os tipos de expressões fixas (máximas, frases feitas, gírias e provérbios), por isso "Fraseologia" e não "Paremiologia". Segundo Obelkevich (1997, p. 45), a diferença entre os provérbios e as frases prontas (por exemplo, "tenho coisas mais importantes a fazer" e "ter um ás na manga") é que estas apresentam uma finalidade mais expressiva do que moral.

${ }^{5}$ Examinei três séries completas dedicadas ao Ensino Fundamental ( $6^{\circ}$ ao $9^{\circ}$ ano), totalizando 12 livros didáticos: Tudo é linguagem, da editora Ática; Português linguagens, da editora Saraiva; e Passaporte para a língua portuguesa, da Editora do Brasil. Não encontrei o gênero provérbio em nenhum desses livros. Em relação às obras dedicadas ao Ensino Médio, examinei uma série ( $1^{\circ}$ ao $3^{\circ}$ ano), Novas palavras, da editora FTD, e um livro dedicado ao $2^{\circ}$ ano, da série Português linguagens, da editora Saraiva, totalizando 4 livros. Nestes também não há menção do gênero proverbial.
} 
formulam uma parte do bom senso de uma sociedade, seus valores e a maneira de fazer as coisas.

De acordo com as palavras do autor, os provérbios podem ser poderosos instrumentos de persuasão, até mesmo conclusivos. Uma vez que eles transmitem uma aura de verdade e de sabedoria popular, passada de geração em geração, aquele que os profere, seja qual for a situação comunicativa, confere autoridade ao seu discurso, legitima-o, e dá-lhe credibilidade, já que suas palavras não são suas, mas da comunidade ou do senso comum que falaram por intermédio dele.

As situações de uso dos provérbios são as mais diversas: são utilizados em conversas no dia a dia, em sermões, em discursos políticos, em inscrições, em músicas, em artigos de revistas e jornais, na publicidade, etc. Também são várias as funções: aconselhar, enfatizar, persuadir, advertir, incentivar, cumprimentar, homenagear, suspeitar, retificar e outros objetivos determinados pelo contexto em que são utilizados.

Schapira (1997, apud Lysardo-Dias, 2004, p. 143) defende o funcionamento paradoxal dos provérbios:

Por um lado, trata-se de uma unidade acabada, isolada; por outro, integra-se a um suporte contextual, com uma função definida. Portanto, teoricamente esse tipo de enunciado é fechado, mas na prática (discursiva), comporta diferentes resignificações. O "já-dito" do enunciado cristalizado projeta-se com um "novo sentido" a cada situação de comunicação.

Baseado na citação, pode-se dizer que os provérbios são enunciados polifuncionais e heterossituacionais. Embora exista em cada provérbio um núcleo significativo constante (funcionaria como uma palavra no dicionário), cada vez que é citado, novos matizes de significado são acrescentados, determinados pelas situações comunicativas. Eles são gêneros em si próprios, mas, necessariamente, se inserem em outros gêneros, que os incorpora e os absorve. Nesse sentido é que Lysardo-Dias (2004, p. 145) os caracteriza como uma espécie de gênero "migrador", uma vez que transitam por outros gêneros, dependendo da situação de uso destes para se realizarem discursivamente.

Obelkevich (1997, p. 53) alerta que há provérbios que se contradizem. Por exemplo, "quem não arrisca não petisca" (ser ousado) e "mais vale um pássaro na mão do que dois voando" (ser moderado), mas na verdade, eles não se anulam. Em todo par contraditório, ambos são verdadeiros, pois cada um será adequado para uma situação específica.

A forma padronizada (estável) faz dos provérbios um gênero facilmente reconhecível. Como aponta Bakhtin (1992, p. 302), "há toda uma gama dos gêneros 
mais difundidos na vida cotidiana que apresenta formas tão padronizadas que o quererdizer individual do locutor quase que só pode manifestar-se na escolha do gênero".

As principais características definidoras do provérbio são: sua concisão; o tempo no presente, sugerindo atemporalidade; podem ser tomados metaforicamente ou literalmente; simetria evidente (paralelismos, repetições, lemas, estruturas bimembres); uso frequente da cópula, dos pronomes pessoais, dos substantivos, de formas imperativas; e recursos estilísticos - aliteração, assonância, rima, metáfora, metonímia, etc. (Junior, 1974, p. 8).

\section{METODOLOGIA}

Para os propósitos desse artigo, foram selecionados e analisados três anúncios publicitários (um de cerveja, um de carro e outro de pneu) veiculados na Revista Veja, anunciados no período de 2002 a 2012. A análise, de natureza qualitativa, tem por objetivo examinar os efeitos de sentido gerados na reconstrução dos provérbios pela publicidade. Para tanto, conto com o apoio teórico de Bakhtin (1994), que considera o gênero pela perspectiva sócio-discursiva, e Miller (1994) e Bazerman (In Dionisio \& Hoffnagel, 2005), que abordam o gênero pela perspectiva da Nova Retórica. A partir de tal aparato teórico e das questões metodológicas para análise dos gêneros propostas por Motta-Roth (In Karwoski, 2006, p. 194), foram escolhidos os principais aspectos a serem explorados: (i) Que ação social se realiza por meio do gênero provérbio e do gênero anúncio publicitário? (iii) Que efeitos ou resultados são pretendidos / causados com a hibridização desses dois gêneros? (ii) Que valores ou ideias são propostos? De acordo com os critérios de análise, verificaremos como a desconstrução e reconstrução dos provérbios trabalha a favor dos propósitos do discurso da publicidade, cujo objetivo principal é encaminhar o receptor, de maneira implícita, à ação, ao ato do consumo.

\section{ANÁLISE DOS DADOS}

Geralmente, elementos imagéticos e verbais são associados nos anúncios publicitários como uma forma de direcionar e intensificar a comunicação persuasiva. A imagem (passível de múltiplas leituras) é ancorada nos elementos linguísticos, que orientam o sentido conveniente pré-estabelecido pelo anunciante (Carvalho, 2003, p. 15). Para a análise, por conta de espaço, consideraremos apenas a parte verbal do anúncio, mas não nos ocuparemos com a análise das características formais do gênero. 
Anúncio (1). Só te falo uma coisa: diga-me no que andas e eu te direi quem és. (anúncio da Renault Sandero GT Line. Veja, ed. 2283, 22/08/12).

Anúncio (2). Pode tirar a coroa. Uma rainha nunca perde a majestade. (anúncio da cerveja BOHEMIA. Veja, ed. 1960, 14/06/06).

\section{Anúncio (3). Quem disse que a pressa é inimiga da perfeição?}

(anúncio da Bridgestone, empresa japonesa de pneus para todos os tipos de veículos, inclusive dos de Fórmula 1. Veja, ed. 1774, 23/10/02).

De imediato, reconhecemos, nos textos acima, enunciados proverbiais incorporados pelos anúncios. Esta identificação é possível pela alta padronização do gênero proverbial. Como afirma Lysardo-Dias (2004, p. 142), enunciados já cristalizados são passíveis de serem reconhecidos, mesmo quando citados parcialmente, desde que o enunciado faça parte dos conhecimentos de mundo do indivíduo.

Acionando nossa memória discursiva, observamos que os provérbios foram alterados. Respectivamente, os anúncios (1), (2) e (3) estão baseados nos originais: "Diga-me com quem andas e eu te direi quem és", "Quem é rei nunca perde a majestade" e "A pressa é inimiga da perfeição". Temos, então, o que Marcuschi denomina de intertextualidade intergêneros. $\mathrm{O}$ gênero anúncio, apesar de tomar a forma do gênero provérbio, continua sendo anúncio, já que o gênero é determinado pela sua função e não por sua forma. Isso fica mais evidente em (1) e (2) e menos em (3), por se apresentar como uma pergunta, embora faça alusão a um provérbio.

De acordo com a Nova Retórica, que concebe os gêneros como ação social, a ação realizada pelos anúncios é a de informar, de modo persuasivo, a venda de um produto, de uma ideia ou de um serviço. Para isso usa das mais variadas estratégias para chamar a atenção do público e conseguir levá-lo ao consumo, configurando, portanto, uma interação comercial entre anunciante e possível cliente. Já a ação do provérbio é de cunho moral: ensina o que se deve fazer ou pensar numa determinada situação e formula certo aspecto do senso comum, os valores e os modos de agir.

$\mathrm{Na}$ definição de Obelkevich (1997, p. 45), os provérbios são "estratégias" munidas de autoridade para situações. Logo, um recurso altamente persuasivo. Dessa forma, a publicidade se utiliza do gênero provérbio, na construção dos anúncios, como uma tática para revestir seu discurso de legitimidade e credibilidade, a fim de atrair a atenção e a adesão do público. Ao modificar os provérbios, o anunciante diz algo novo em cima do que já foi dito antes. É uma forma de provocar reflexões e operações mentais no leitor, funciona como um convite (ou desafio) para que ele resgate o sentido 
original do provérbio, compare com a nova construção apresentada e interprete qual a mensagem do anúncio. Trata-se de um resultado psicológico que poderá ficar no inconsciente do cliente e conduzir a ações concretas de aquisição do produto. Além disso, o anúncio em forma de provérbio "camufla" o objetivo puramente comercial, no qual o leitor é visto apenas como consumidor. A relação comercial cede lugar a uma relação mais "amigável”, uma vez que uma das funções do provérbio é aconselhar e advertir.

Assim, o efeito de sentido presente em (1) é que podemos ser julgados pelo veículo que utilizamos como meio de transporte. $\mathrm{O}$ anúncio apela para a vaidade pessoal do receptor, o carro é apresentado como símbolo de status. A ideia é que andar no Renault Sandero faz a pessoa se destacar e parecer que é "alguém" na vida, que é bemsucedida. Ou seja, os valores implícitos aqui remetem ao fato de as pessoas serem julgadas e apreciadas pelo que têm e não pelo que são.

Em (2), ao relacionar o sentido do provérbio original - que diz respeito às qualidades da pessoa, independente das circunstâncias - entendemos o sentido do anúncio como uma constatação ou o reconhecimento de um fato: a cerveja Bohemia é nobre, soberana, especial. A ideia implícita é que, independente da concorrência, ela sempre se destacará das outras cervejas. Em outras palavras, o enunciado poderia ser entendido assim: "fica tranquila, as outras cervejas não estão à sua altura". O interessante é que, nesse anúncio, o anunciante não dialoga com o leitor (pelo menos não explicitamente), mas com a própria cerveja, como se esta fosse uma pessoa. Compreendemos, então, que essa estratégia discursiva é uma forma de tentar convencer o receptor de que ele, ao optar pela compra da Bohemia, está consumindo a melhor cerveja. Como os provérbios são atemporais, é uma forma de dizer também que essa posição majestosa da Bohemia é permanente.

Para finalizar, em (3) nos deparamos com uma pergunta, que estabelece um diálogo ainda mais direto com o leitor. Aqui a desconstrução do provérbio original se dá pela contestação, pondo em dúvida o saber do senso-comum. Notemos, porém, que o anúncio trabalha com o sentido literal do provérbio original e não o metafórico, como acontece geralmente. $\mathrm{O}$ efeito de sentido causado é: nem sempre os provérbios são verdadeiros. Há situações em que eles não se aplicam. A ideia é que, tratando-se de pneus de Fórmula 1, por exemplo, quanto mais rápido, melhores os resultados (mais perfeitos). 


\section{CONSIDERAÇÕES FINAIS}

Como afirma Miller (1994, p. 38), dominar um gênero é uma forma de realizar linguisticamente objetivos específicos em situações sociais particulares. Portanto, o anúncio publicitário se utiliza dos provérbios - gêneros estabelecidos culturalmente - e os reinventa para comunicar algo novo e interagir com o público. Embora simule um evento comunicativo entre amigos, em que o anunciante, por meio do gênero anúncioprovérbio, aconselha que postura ou atitude seu "amigo cliente" deve tomar, a situação social continua sendo estritamente comercial. E o objetivo específico, a prédeterminação de comportamentos desejáveis, ou seja, que o consumidor compre o produto.

Uma importante ideia que não se pode deixar de registrar é que dentro do trabalho de ensino de língua materna, os gêneros são um recurso didático muito eficiente no desenvolvimento da competência comunicativa dos alunos. Desde que não sejam utilizados apenas como pretexto para o ensino da gramática, que é insuficiente para a formação leitora e a boa expressividade. Não basta aprender a gramática, é necessário refletir sobre o texto, compreender o dito e o não dito, interpretar, produzir sentido e, sobretudo, fazer uso da língua de forma adequada aos diferentes contextos comunicativos. A educação, sendo uma prática social, não pode se restringir à teoria, sem o compromisso com a realidade local e com o mundo em que vivemos.

Deste modo, é importante o professor explorar materiais autênticos em sala de aula (revistas, jornais, etc.), pois neles se encontram gêneros que fazem parte do dia a dia da sociedade em geral. Mostrar aos alunos as possibilidades de emprego dos provérbios nas mais diversas situações comunicativas é uma forma de ensiná-los a produzir discursos mais convincentes, aumentando as chances de realizarem seus propósitos. E o anúncio publicitário, por fazer parte de seu cotidiano desde a tenra idade e, em muitos casos, influenciar seus comportamentos e desejos de compra, permite ao professor demonstrar os mecanismos linguísticos e persuasivos envolvidos no processo de sua construção. A adequada mediação docente, na análise dos diferentes efeitos de sentido inferidos dos anúncios publicitários, contribui para o desenvolvimento da competência do aluno como leitor crítico das mensagens publicitárias. 


\section{REFERÊNCIAS}

Bakhtin, M. (1992). Os gêneros do discurso. In Estética da criação verbal, pp. 278-326. São Paulo: Martins Fontes.

Bazerman, C. (2005). Atos de fala, gêneros textuais e sistemas de atividades: como os textos organizam atividades e pessoas. In: Angela Dionisio \& Judith Hoffnagel (orgs.) Gêneros textuais, tipificação e interação: Charles Bazerman. São Paulo: Cortez.

Carvalho, G. (2005). Gênero como ação social em Miller e Bazerman: o conceito, uma sugestão metodológica e um exemplo de aplicação. In José Luiz Meurer; Adair Bonini; Désirée MottaRoth (orgs.) Gêneros: teorias, métodos, debates. São Paulo: Parábola.

Carvalho, N. (2003). Publicidade: a linguagem da sedução. 3. ed. São Paulo: Ática.

Costa, S. R. (2009). Dicionário de gêneros textuais. 2. ed. Belo Horizonte: Autêntica.

Hyon, S. (1996). Genre in three traditions: implications for ESL. TESOL Quarterly, 30, 4, pp. 693-722.

Junior, R. M. (1974). Dicionário brasileiro de provérbios, locuções e ditos curiosos. Rio de Janeiro: Documentário.

Lysardo-Dias, D. (2004). Características e funcionalidade discursiva do gênero proverbial. In Machado, I. L. \& Mello, R.1. (orgs.) Gêneros: Reflexões em Análise do Discurso. Belo Horizonte: NAD/FALE/UFMG.

Marcuschi, L. A. (2002). Gêneros textuais: definição e funcionalidade. In Angela Paiva et al (orgs.) Gêneros Textuais \& ensino. Rio de Janeiro: Lucerna.

Miller, C. (1994). Genre as social action. In: Aviva Freedman \& Peter Medway (eds.) Genre and the new rhetoric. London: Taylor \& Francis.

Monnerat, R. S. (2003). A publicidade pelo avesso: propaganda e publicidade, ideologias e mitos e a expressão da idéia - o processo de criação da palavra publicitária. Niterói: EdUFF.

Motta-Roth, D. (2006). Questões de metodologia em análise de gêneros. In Acir Mário Karwoski, Beatriz Gaydeczka \& Karim Siebeneicher Brito (orgs.) Gêneros textuais: Reflexões e ensino. $2^{\mathrm{a}}$ ed. Rio de Janeiro: Lucerna.

Obelkevich, J. (1997). Provérbios e história social. In P. Burke e R. Porter (orgs.) História social da linguagem. São Paulo: UNESP.

Paiva, V. L. E-mail: Um novo gênero textual. In Marcushi, A. \& Xavier, A. C. (orgs.) Hipertexto e generos digitais: Novas formas de construção de sentido. P. 68-90. Rio de Janeiro: Lucerna.

Paré, A. \& Smart, G. (1994). Observing genres in action: Towards a research methodology. In: Aviva Freedman \& Peter Medway (eds.) Genre and the new rhetoric. London: Taylor \& Francis.

Rojo, R. (2005). Gêneros do discurso e gêneros textuais: Questões teóricas e aplicadas. In José Luiz Meurer; Adair Bonini; Désirée Motta-Roth (orgs.) Gêneros: teorias, métodos, debates. São Paulo: Parábola.

Sabrina, J. \& Heberle, V. (2002). Análise crítica do discurso de um folder bancário. In J. L. Meurer \& D. Motta-Roth (orgs.). Gêneros textuais. São Paulo: EDUSC. 
Schipper, M. (2012). Nunca se case com uma mulher de pés grandes: a representação da mulher no dito popular. Rio de Janeiro: Bertrand Brasil.

Sandmann, A. J. (2005). A linguagem da propaganda. 8 ed. São Paulo: Contexto.

\section{A AUTORA}

Crisvânia Santos é graduada em Letras pela FIC (Faculdades Integradas CampoGrandenses) e mestranda no Programa de Pós-Graduação em Estudos da Linguagem da Pontifícia Universidade Católica do Rio de Janeiro. Atua como professora de Língua portuguesa nos anos finais do Ensino Fundamental.

E-mail: $\underline{\text { crisvania1 @ gmail.com }}$

\section{ANEXOS}
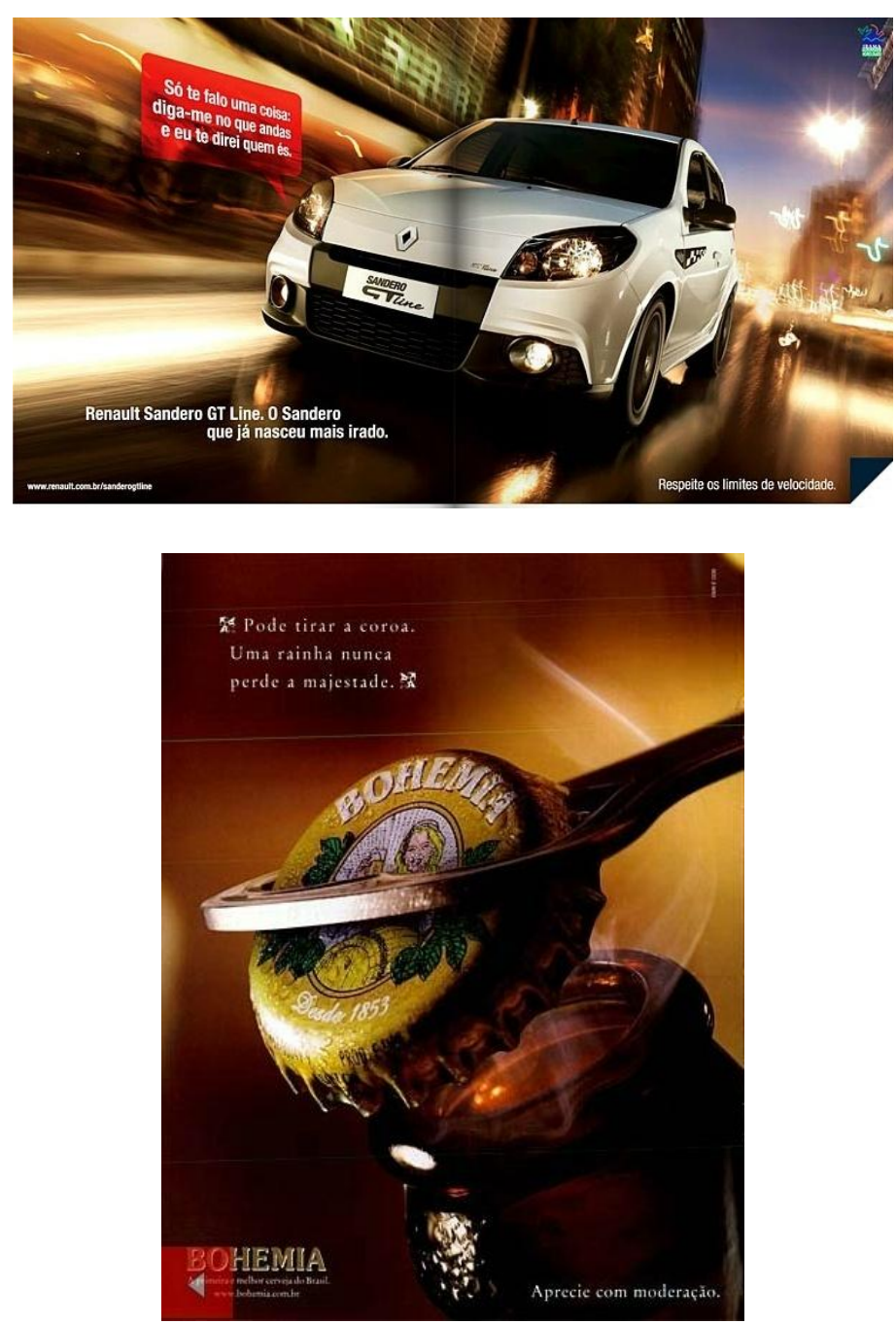


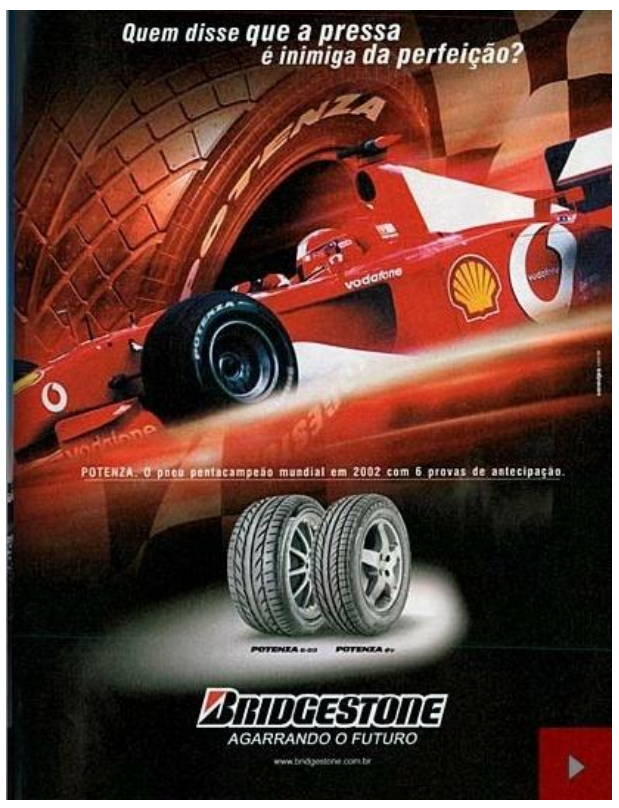

